\title{
Major Challenges and Barriers to IPSASs Implementation in Lebanon
}

\author{
Amar SAYED AHMAD \\ The Bucharest University of Economic Studies, Bucharest, Romania \\ Amar_s_a@hotmail.com \\ HasSan NASSEREDINE \\ The Bucharest University of Economic Studies, Bucharest, Romania \\ Hassan.Nasseredine@gmail.com
}

\begin{abstract}
The need for greater accountability and transparency in government and private institutions handling funds and resources reporting was heightened by the global financial crisis that led to reduced resources available for both the government and private sector. This led to the introduction of an accounting and auditing system known as International Public Sector Accounting Standards (IPSASs) that will help to track all transactions hence ability to maintain transparency and accountability while reporting financial statements. However, the implementation of the IPSASs guidelines in most countries has been faced with a lot of barriers. Therefore, the purpose of this report is to determine some of the challenges facing the implementation of IPSASs in Lebanon. The study deploys quantitative descriptive study design and the primary data gathered using a semi-structured questionnaire from 100 public accountants and financial system managers. The data collected has been analyzed using SPSS to get frequencies and percentages which have been presented in tabular form. The findings indicate that the level of IPSAS awareness in Lebanon is higher, however, the full implementation of the IPSASs guidelines is still facing a lot of barriers. The principal obstacles that have come out clearly from the study findings included lack of government support, the high cost of implementation, resistance to change and lack of better understanding of the significance and operation of the IPSASs tool. The study has recommended that IPSASs be incorporated in college and university curriculum, the government to fund the implementation of IPSASs in all listed organizations and government departments and strengthen regulatory bodies to ensure that all accountants and auditing organizations in Lebanon comply with IPSASs guidelines.
\end{abstract}

Keywords: IPSASs, IPSASs Implementation, Accountability and Transparency, Lebanese Public Accounting System, Barriers, And Challenges.

\section{Introduction}

Organizations and government agencies at all levels are more preoccupied with the preparation and presentation of the financial statements to ensure that accountability and transparency are maintained. Accountability and transparency are the key indicators that can be relied upon to maintain trust and honesty in handling public funds in both public and private organizations (Aliyu, \&Balaraba, 2014). The organization management often emphasizes about the challenges pertaining to corruption, non-accountability and funds misappropriation.

Numerous legislations and strategies exist to ensure accountability and transparency in public funds utilizations, however there is still significant increase in the cases of reported DOI: 10.2478/picbe-2019-0029, pp. 326-334, ISSN 2558-9652| Proceedings of the $13^{\text {th }}$ International Conference on Business 
misappropriated public funds and properties in Lebanon (Gourwinkel, 2016). Moreover, Lebanon is reported to exhibit substantial influx of remittance from various organizations agencies and this is estimated by the World Bank at approximately $\$ 7.5$ billion annually (Rogosic, \& Palos, 2017). Embezzlement of both public and private funds operations including the money laundering and cyber money thefts exponentially increased in 2015. The rate at which the financial and operations activities of the Lebanese government organizations and private organizations are reported has raised a lot of concerns at both national and international levels.

The key weaknesses in Lebanese organizations have been identified as lack of financial accountability and poor reporting of the organization performance. It was suggested that the most effective means of achieving accountability in the Lebanese organizations is to master the basis of accounting and legislations that would meet the national and international requirements reporting policies (Adamu, \& Ahmed, 2014).

According to the principles of agency theory, organizations dealing with funds and properties that can be equated to monetary forms are obliged to provide a proper account on how funds and properties are utilized (Pozzoli, \& Ranucci, 2013). The organization shareholders, stakeholders and the members of the public often call for higher levels of accountability and transparency in areas of fiscal spending (Kalulu, 2015). The study performed by the World Bank in 1992 found out that there is a strong relationship between the good governance and high level of performance, hence the need to ensure that appropriate accounting methods are deployed in organizations. The outcome of the study by the World Bank in 1992 led to the introduction of International Public Sector Accounting Standards (IPSASs). The purpose of IPSASs was to improve the management and the control of resources in the public sector through appropriate reporting of financial statements (Pozzoli, \&Ranucci, 2013).

IPSASs is a legislative provision accredited to provide a transparent and accurate financial overview of governments and listed organizations across the globe by deploying accrual accounting as opposed to cash accounting. The full adoption of IPSASs in the public sector has the potential of radically changing the accounting and financial reporting practices, hence the ability to eliminate corruption cases in the public sector (Majzoub, \& Aga, 2015).

The implementation of IPSASs in Asian countries including Lebanon is facing a lot of challenges. According to the report by Ryan, Guthrie, \& Day (2008), Lebanon is using the IPSASs system however in a much weaker form. Therefore, there is a need to strengthen the strategies put in place to monitor IPSASs implementation in Lebanon. The strategies can be improved through collaboration with the competent authorities such as International Public Sector Accounting Standards Board (IPSASB) to train accountants and financial managers in Lebanon. The training will improve the efficiency of the staff using the IPSASs guidelines (Barton, 2009). Lebanese accountants have also been experiencing challenges with IPSASs implementation, such as difficulties in valuing particular asset types, incomplete or absence or inaccurate records to determine the opening balance and complex financial instruments. In order to reduce the corruption incidences and funds misappropriation in Lebanon, IPSASs was introduced as the functional unit for holistic reporting of all financial transactions and positions (Adejola, 2012). 
Baboojee (2011) stated in his report that, while most government agencies and business organizations in Lebanon have adopted IPSASs wholly, some have opted to modify the standards to meet their specific needs. Most users have argued that the advertised benefits of IPSASs do not justify the costs of its implementation since the adoption of the tool is quite expensive. As such, it is not established in Lebanon whether the application of IPSASs has economic significance.

PICBE | 328

The broad objective of this research study is to identify the challenges facing implementation of IPSASs to ensure fiscal accountability in Lebanon. The specific objectives will include to assess the impacts of implementation of IPSASs on accounting systems in Lebanon and to determine the staff awareness and compliance with the IPSASs requirements in managing accounting systems in Lebanon.

\section{Literature review}

\section{The IPSASs Concept}

Aliyu, \&Balaraba (2014) stated that the need for greater accountability and transparency in government institutions handling funds and resources was heightened by the global financial crisis which led to reduced resources available for both the government and private sector. During the financial crisis time, Gourwinkel (2016) reported that there was insufficient data about financial statements hence making it difficult for countries to predict and prevent a sovereign liquidity crisis. Therefore, a tentative agreement was reached to deploy an initiated financial management reform programs that would attract foreign direct investments in multiple countries (Ofoegbu, 2014). Adopting the accrual accounting as part of the broader reform programs was highly welcomed by most nations hence encouraging countries across the world to make financial statements concerning the adoption of standards based on cash IPSASs or the accrual IPSASs (Ryan, Guthrie, \& Day, 2008).

Different counties have taken different approaches to adopt IPSASs in their financial systems. Some countries have wholly embraced the IPSASs provisions while other countries -such as Lebanon -have slightly modified the standards (Pozzoli, \&Ranucci, 2013). As such, the level of success with the standards greatly varies from one country to another with other countries failing to realize the significance of the standards totally. The adoption of IPSASs has gained momentum across the world hence no country should be left out. The common goal while implementing IPSASs guidelines is to ensure transparency and accountability in government and private financial reporting (Baboojee, 2011). The guidelines are highly significant after the studies have indicated that IPSASs has the potential of drastically reducing the malpractices in accounting and financial reporting systems (Adamu, \& Ahmed, 2014).

\section{Benefits of IPSAS}

The study conducted by Majzoub, \& Aga (2015) on the IPSASs implementation in European nations indicates that IPSASs adoption provides significant and common advantages, yet challenges are still striking in the roadmap to full adoption of the standards. The key benefits of IPSASs pointed out by Kalulu (2015) include greater accountability and transparency, better decision making, improved decision making, and data consistency and application. The financial statements prepared using the IPSASs guidelines capture all income and 
expenditure as well as owns and owes hence the ability to track the movement of funds easily. Thus, it becomes easy to curb frauds and corruption cases (Barton, 2009).

The knowledge of the financial position of an organization entity helps to develop future strategies and better financial judgments. The IPSASs legislations have made it easy for auditors to deliver effective audits that help to mitigate risks. IPSASs also streamline standards reporting processes hence helping to support the consolidation of all financial activities. Other benefits of IPSASs as discussed by Adejola (2012) include enabling sound financial management, enhance professionalization and access to talent, and enhance international comparability, government stability and the broader economic and social performance of an organization.

\section{Challenges and Roadmap to Adoption of IPSASs}

There is still a wide variation in the rate of progress and success made with the adoption of IPSASs. Specific complex and consistent implementation challenges face the implementation of the IPSASs more so in the Asian countries and part of African countries (Ryan, Guthrie, \& Day, 2008). The challenges facing the implementation of IPSASs can be classified into stakeholder engagement challenges, legal and structural transformational challenges, change management issues, skills capacity, the cost of implementation, the technological and infrastructural challenges, implementation approaches adopted by the nations and the external supports (Adamu, \& Ahmed, 2014).

Barton (2009) has indicated that the level of awareness and understanding of the IPSASs framework greatly varies across the jurisdictions. The level of knowledge on the IPSASs guidelines differs across the public sector entities, political class and the academicians accustomed to cash accounting principles. The success of IPSASs application depends on understanding, engagement, and education of the key stakeholders (Aliyu, \&Balaraba, 2014). Failure to engage the staff members in developing a stronger partnership between audit and finance departments in an organization led to the unsuccessful application of the IPSASs. The resistance by auditors and accountants to introduce the IPSASs guidelines in an organization has also resulted in the unsuccessful deployment of the standards in most countries (Kalulu, 2015).

The financial costs and resource costs of implementing IPSASs are too high, hence most countries are reluctant to introduce the provisions in their financial management systems (Ofoegbu, 2014). The external support from the professional accounting organizations are required to enhance awareness of the need to realize accountability and transparency in financial reports is also a factor that can contribute to successful implementation of IPSASs. Therefore, failure to incorporate external support may lead to failure (Rogosic, \& Palos, 2017).

\section{Methodology}

The study was performed in Lebanon among accountants. The sample size of 100 participants was selected randomly among the accountants practicing in Lebanon. The sample size was calculated using the below formula:

$$
n=N /\left(1+a^{2} N\right)
$$


Where,

N population

a alpha level at 0.05

n estimated sample size

PICBE | 330

The study deployed a quantitative cross-sectional study design. The primary data was collected using a Likert five scale semi-structured questionnaire. The five Likert Scales deployed in the questionnaire were Strongly Agree (5), Agree (4), Undecided (3), Disagree (2) and Strongly Disagree (1). The questionnaire used in the study was divided into three sections. Section one entailed pre-qualifying information, section two composed demographic data about the study participant and section three entailed queries on the use of IPSASs. The primary data gathered was entered into and analyzed using the Statistical Package for the Social Science (SPSS). The data were analyzed using descriptive statistics such as frequency and percentages in a tabulated format.

\section{Results and discussions}

The data were successfully collected from 100 participants among them 47 females and 53 males (Table 1). Majority of the respondents were aged between 31 and 40 years, followed by 42-52 age bracket (Table 2). $94 \%$ of the participants in the study occupy the position of accounting or finance department in the government agencies in Lebanon, and only $6 \%$ of the respondents are not occupying the position of accounting or finance in government (Table 3). As such, the study correctly targeted individuals who are likely to be using IPSASs in their daily operations. $60 \%$ of the respondents confirmed to be responsible for collecting financial data and preparing financial reports for Lebanon government (Table 4). As such, it is likely that the majority respondents have faced some challenges with IPSASs tool. More than half of the respondents (54\%) confirmed that they are familiar with IPSASs and the majority of them had done Bachelor degree and PhD education level (Table 5 and 6 respectively).

The research findings have indicated that the challenges facing the deployment of IPSASs in Lebanon include lack of comprehensive understanding of IPSASs requirements that applies in accounting practices, lack of prior experience with the IPSASs, lack of government support to promote the use of IPSASs, high cost of IPSASs implementation and poor integration of the technology that challenges the flow of financial information (Rogosic, \& Palos, 2017). The findings on table 7 (R/Q. 7) show that more than $50 \%$ of the respondents agree that IPSASs implementation is associated with high cost. The findings are in agreement with what was reported by Adamu, \& Ahmed (2014) and Ofoegbu (2014) that the resources required to roll out IPSASs fully are quite expensive.

Lack of IPSASs-related training has the potential of reducing the confidence and willingness of the accountants and finance managers to use IPSASs guidelines. The statement is supported by $84 \%$ of the respondents hence confirming the study findings performed by Baboojee (2011) to determine factors that are likely to enhance the application of IPSASs in ensuring financial accountability and transparency. The study has also elucidated that most institutions are not flexible enough to adapt to the changes required by the IPSASs guidelines. 
$55 \%$ of the respondents disagreed that institutions are flexible enough to adapt to the changes, hence another key challenge facing the implementation of IPSASs in Lebanon. 69\% of the respondents confirmed that they do not have prior experience with IPSASs hence the possible reason for change resistance.

Lack of government support is also another barrier to IPSASs implementation in Lebanon. $60 \%$ of the respondents have agreed that the government has not shown any effort to support the policy implementation. The majority of the respondents (41\%) haven't decided if the government recognizes the value of IPSASs in ensuring accountability and transparency, hence the possible reason for lack of interests to support the implementation of IPSASs in Lebanon.

$76 \%$ of the respondents have agreed that the organizations they are working for do not have the technical resources to adopt IPSASs guidelines. This could also be the possible reason why most organizations in Lebanon are still resistant to embrace the IPSASs in their financial management systems and auditing practices. This can also be attributed to the fact that most respondents are undecided whether IPSAS's benefits overweigh the implementation costs or not (Gourwinkel, 2016).

\section{Figures and tables}

Table1: Gender of the respondents

\begin{tabular}{|cc|r|r|r|}
\hline & \multicolumn{2}{|c|}{ Frequency } & Valid Percentage & \multicolumn{1}{c|}{$\begin{array}{l}\text { Cumulative } \\
\text { Percentage }\end{array}$} \\
\hline Valid & Female & 47 & 47.0 & 47.0 \\
& Male & 53 & 53.0 & \\
& Total & 100 & 100.0 & 100.0 \\
\hline
\end{tabular}

Source: Author's own research

Table 2: Age of the respondents

\begin{tabular}{|l|r|r|r|}
\hline & Frequency & Valid Percentage & Cumulative Percentage \\
\hline Valid & & & \\
20-30 years & 4 & 4.0 & 4.0 \\
31-40 years & 46 & 46.0 & 50.0 \\
42-50 years & 24 & 24.0 & 74.0 \\
51 years and above & 26 & 26.0 & \\
Total & 100 & 100.0 & 100.0 \\
\hline
\end{tabular}

Source: Author's own research

Table 3: Occupy position in accounting or finance department of a government agency in

Lebanon

\begin{tabular}{|l|r|r|r|}
\hline & Frequency & Valid Percentage & Cumulative Percentage \\
\hline Valid & & & \\
Yes & 94 & 94.0 & 94.0 \\
No & 6 & 6.0 & \\
Total & 100 & 100.0 & 100.0 \\
\hline
\end{tabular}

Source: Author's own research

Table 4: Responsible for collecting financial data and preparing financial reports for a Lebanese government agency

DOI: $10.2478 /$ picbe-2019-0029, pp. 326-334, ISSN 2558-9652| Proceedings of the $13^{\text {th }}$ International Conference on Business Excellence 2019 


\begin{tabular}{|l|r|r|r|}
\hline & Frequency & Valid Percentage & Cumulative Percentage \\
\hline Valid & & & \\
Yes & 60 & 60.0 & 60.0 \\
No & 40 & 40.0 & 100.0 \\
Total & 100 & 100.0 & \\
& & & 100.0 \\
\hline
\end{tabular}

Source: Author's own research

Table 5: Aware of International Public Sector Accounting Standards

\begin{tabular}{|l|r|r|r|}
\hline & Frequency & Valid Percentage & \multicolumn{2}{|c|}{$\begin{array}{c}\text { Cumulative } \\
\text { Percentage }\end{array}$} \\
\hline Valid & 54 & 54.0 & 54.0 \\
Yes & 46 & 46.0 & 100.0 \\
No & 100 & 100.0 & \\
Total & & & \\
& & & \\
\hline
\end{tabular}

Source: Author's own research

Table 6: Level of Education

\begin{tabular}{|l|r|r|r|}
\hline & Frequency & Valid Percentage & \multicolumn{2}{c|}{$\begin{array}{c}\text { Cumulative } \\
\text { Percentage }\end{array}$} \\
\hline Valid College diploma & 6 & 6.0 & 6.0 \\
Bachelor's degree & 43 & 43.0 & 49.0 \\
Master's degree & 45 & 45.0 & 94.0 \\
Ph. D. & 6 & 6.0 & 100.0 \\
Total & 100 & 100 & \\
\hline
\end{tabular}

Source: Author's own research

Table 7 showing the frequencies and percentages about the use of IPSASs in Lebanon

\begin{tabular}{|c|c|c|c|c|c|c|}
\hline $\mathrm{R} / \mathrm{Q}$ & THE USE OF IPSASs & 1 & 2 & 3 & 4 & 5 \\
\hline & & $\begin{array}{l}F \\
(\%)\end{array}$ & $\begin{array}{l}\mathrm{F} \\
(\%)\end{array}$ & F (\%) & $\begin{array}{l}F \\
(\%)\end{array}$ & $\begin{array}{l}\mathrm{F} \\
(\%)\end{array}$ \\
\hline 1 & $\begin{array}{l}\text { There are opportunities for staff training and } \\
\text { recruitment in IPSAS. }\end{array}$ & $\begin{array}{l}10 \\
10.0\end{array}$ & $\begin{array}{l}14 \\
14.0\end{array}$ & $\begin{array}{l}26 \\
26.0\end{array}$ & $\begin{array}{l}34 \\
34.0\end{array}$ & $\begin{array}{l}16 \\
16.0\end{array}$ \\
\hline 2 & $\begin{array}{l}\text { The lack of IPSAS-related training reduces } \\
\text { confidence and willingness to adopt IPSAS } \\
\text { principles. }\end{array}$ & 11.0 & $4 \quad 4.0$ & $\begin{array}{l}11 \\
11.0\end{array}$ & $\begin{array}{l}62 \\
62.0\end{array}$ & $\begin{array}{l}22 \\
22.0\end{array}$ \\
\hline 3 & $\begin{array}{l}\text { The institutional organization is flexible } \\
\text { enough to adapt to changes required by the } \\
\text { IPSAS implementation. }\end{array}$ & $\begin{array}{l}15 \\
15.0\end{array}$ & $\begin{array}{l}40 \\
40.0\end{array}$ & $\begin{array}{l}21 \\
21.0\end{array}$ & $\begin{array}{l}17 \\
17.0\end{array}$ & $\begin{array}{l}7 \\
7.0\end{array}$ \\
\hline
\end{tabular}

DOI: 10.2478/picbe-2019-0029, pp. 326-334, ISSN 2558-9652| Proceedings of the $13^{\text {th }}$ International Conference on Business Excellence 2019 


\begin{tabular}{|c|c|c|c|c|c|c|}
\hline 4 & $\begin{array}{l}\text { The fixed and hierarchal structure of } \\
\text { government agencies challenges the IPSAS } \\
\text { implementation. }\end{array}$ & $\begin{array}{ll}0 & 0.0\end{array}$ & $\begin{array}{l}11 \\
11.0\end{array}$ & $\begin{array}{l}13 \\
13.0\end{array}$ & $\begin{array}{l}61 \\
61.0\end{array}$ & $\begin{array}{l}15 \\
15.0\end{array}$ \\
\hline 5 & $\begin{array}{l}\text { Poor integration of technology challenges the } \\
\text { flow of financial information and the } \\
\text { adoption of IPSAS }\end{array}$ & 0.0 & $\begin{array}{l}24 \\
24.0\end{array}$ & $\begin{array}{l}14 \\
14.0\end{array}$ & $\begin{array}{l}41 \\
41.0\end{array}$ & $\begin{array}{l}21 \\
21.0\end{array}$ \\
\hline 6 & $\begin{array}{l}\text { My organization lacks technical resources to } \\
\text { adopt IPSAS. }\end{array}$ & 1.0 & $\begin{array}{l}12 \\
12.0\end{array}$ & $\begin{array}{l}11 \\
11.0\end{array}$ & $\begin{array}{l}55 \\
55.0\end{array}$ & $\begin{array}{l}21 \\
21.0\end{array}$ \\
\hline 7 & $\begin{array}{l}\text { The IPSAS implementation is associated with } \\
\text { high costs. }\end{array}$ & $\begin{array}{l}25 \\
25.0\end{array}$ & $\begin{array}{l}11 \\
11.0\end{array}$ & $\begin{array}{l}14 \\
14.0\end{array}$ & $\begin{array}{l}36 \\
36.0\end{array}$ & $\begin{array}{l}14 \\
14.0\end{array}$ \\
\hline 8 & $\begin{array}{l}\text { The benefits associated with IPSAS } \\
\text { overweigh implementation costs. }\end{array}$ & 6.0 & $\begin{array}{l}17 \\
7.0\end{array}$ & $\begin{array}{l}45 \\
45.0\end{array}$ & $\begin{array}{l}27 \\
27.0\end{array}$ & $\begin{array}{l}5 \\
5.0\end{array}$ \\
\hline 9 & $\begin{array}{l}\text { There is no policy supporting or promoting } \\
\text { the IPSAS use. }\end{array}$ & 0.0 & $\begin{array}{l}12 \\
2.0\end{array}$ & $\begin{array}{l}28 \\
28.0\end{array}$ & $\begin{array}{l}48 \\
48.0\end{array}$ & $\begin{array}{l}12 \\
12.0\end{array}$ \\
\hline 10 & $\begin{array}{l}\text { The government recognizes the values of } \\
\text { accountability and transparency. }\end{array}$ & $\begin{array}{l}15 \\
15.0\end{array}$ & $\begin{array}{l}26 \\
6.0\end{array}$ & $\begin{array}{l}41 \\
41.0\end{array}$ & $\begin{array}{l}10 \\
10.0\end{array}$ & $\begin{array}{l}8 \\
8.0\end{array}$ \\
\hline 11 & $\begin{array}{l}\text { I have prior experience in using IPSAS in } \\
\text { creating financial statements. }\end{array}$ & $\begin{array}{l}24 \\
24.0\end{array}$ & $\begin{array}{l}45 \\
45.0\end{array}$ & $\begin{array}{ll}6 & 6.0\end{array}$ & $\begin{array}{l}18 \\
18.0\end{array}$ & $\begin{array}{l}7 \\
7.0\end{array}$ \\
\hline 12 & $\begin{array}{l}\text { I lack a comprehensive understanding of } \\
\text { IPSAS requirements when applied to the } \\
\text { accounting practice. }\end{array}$ & $\begin{array}{l}10 \\
10.0\end{array}$ & $\begin{array}{l}29 \\
29.0\end{array}$ & $\begin{array}{l}14 \\
14.0\end{array}$ & $\begin{array}{l}37 \\
37.0\end{array}$ & $\begin{array}{l}10 \\
10.0\end{array}$ \\
\hline
\end{tabular}

\section{Conclusion}

Source: Author's own research

The study sought to determine the challenges facing IPSASs implementation in Lebanon and the level of awareness among the accountants, auditors and the financial system managers. The study has found that the level of IPSASs awareness in Lebanon is high. However, the full implementation of the IPSASs guidelines is still facing a lot of barriers. The key barriers that have come out clearly from the study findings included lack of government support, a high cost of implementation, resistance to change and lack of better understanding of the significance and operation of the IPSASs tool. Accountability and transparency are the key values to maintain while working in both public and private financial departments. The IPSASs is a significant tool that can ensure accountability and transparency in financial system management when well implemented. The IPSASs tool has other benefits such as ensuring better decision making, improved decision making, and data consistency and application hence it should be fully implemented. The following are recommended for Lebanon government and financial system managers:

i. The IPSASs guidelines should be incorporated as part of a training program for students undertaking accounting and finance courses in both colleges and universities. This will enhance understanding of the IPSASs concept and its significance and ability to embrace the guidelines.

ii. The government should set aside enough funds to support the implementation of the IPSASs in all financial organizations and government agencies in Lebanon as a way of relieving the organizations from the cost burdens.

iii. Finally, the government should strengthen the auditing firms across Lebanon to ensure that they are complying with IPSASs provisions. Auditing 
organizations that fail to comply with IPSASs guidelines should be deregistered or suspended from operating in Lebanon

\section{References}

Adamu, S.A, \& Ahmed, A.D. (2014). IPSAS and Lebanon public sector: The challenges of firsttime adopters. International Journal of Social Sciences and Humanities Innovations, 2(1), 151-160.

Adejola, P.A. (2012) International public sector accounting standards: Practical implementation guide. Rainbow Prints, Abuja

Aliyu, A. \& Balaraba, A. (2014). IPSASs and financial and financial reporting in Nigeria: Answer to implementation questions. Journal of Economics and Finance (IOSR - JEF), 6(6), 28-32.

Baboojee, B. (2011). Improving service delivery through changing from cash to accrual accounting: Lessons for South Africa based on a cross-national study. Research report presented in partial fulfillment of the requirements for the degree of Master of Development Finance at the University of Stellenbosch

Barton, A. (2009). The use and abuse of accounting in the public sector financial management reform program in Australia. ABACUS, 5(2), 221-248.

Gourwinkel, D. (2016). Building alliances, gaining public trust: Chile's financial management reforms. International Journal of Social Sciences and Humanities Innovations, 4(9), 151-160.

Kalulu, W. Y. (2015). IFAC Roundtable Meeting: Practical implementation experience of IPSAS Accrual Basis. The Japanese style of business accounting, pp. 17-31, Westport: Quorum Books.

Majzoub, S., \& Aga, M., (2015), "Characterizing the gap between accounting education and practice: Evidence from Lebanon," International Journal of Business and Management 10(12): $127-151$.

Ofoegbu, G. N., (2014), "New public management and accrual accounting basis for transparency and accountability in the Nigerian public sector," IOSR Journal of Business and Management (IOSR-JBM) 16(7): 104-113.

Pozzoli, M., \& Ranucci, S., (2013), "The process of implementing the accounting harmonization in the Italian local governments: The case of Prato", International Journal of Business Research and Development 2(3): 1-18.

Rogosic, A., \& Palos, K. P., (2017), "Public sector accounting: Transparency issues”, European Scientific Journal 13-23.

Ryan, C., Guthrie, J., \& Day, R., (2008), "Politics of financial reporting and the consequences for the public sector," A Journal of Accounting, Finance and Business Studies 43(4): 474487. 